Марјана Розенфељд Софија Заболотнаја

Вороњешки државни универзитет

(Вороњеж, Русија) $81^{\prime} 23$

https://doi.org/10.18485/filkult.2016.2.ch17

\title{
КЉУЧНЕ РЕЧИ УМЕТНИЧКОГ ТЕКСТА КАО ПРЕДМЕТ ПСИХОЛИНГВИСТИЧКОГ ИСТРАЖИВАњА
}

\section{Сажетак}

Један од нарочито актуелних задатака у савременим књижевним студијама је савладање текстоцентричног приступа и, као резултат, концентрација на «живом» аутору, аутору као субјекту дискурсивне праксе. Ово може бити остварено у поређењу уметничког текста и «свакодневног» говора аутора. Као индикатор њиховог дотицаја служе кључне речи ауторског текста, или маркеме (дефиницију маркема види у следећем раду Алексеја А. Кретова: Кретов А.А. Понятие маркемы: методика выявления и практика использования / А.А. Кретов // Универсалии русской литературы 2. Сборник статей / Под ред. А.А. Фаустова. - Воронеж: НАУКА-ЮНИПРЕСС, 2010, С.138-153).

Ова комплексна методика истраживања уметничког текста је основана на поређењу деловања ауторских маркема у уметничком тексту и у индивидуалном коришћењу речи код аутора. Такво поређење постаје могуће преко низа разноврсних психолингвистичких експеримената, кад у истраживању узме учешће биографски аутор, а маркеме узете из његових текстова бивају укључене у еспериментални списак речи.

Серија експеримената укључује слободни асоцијативни експеримент, усмерени асоцијативни експеримент (рестриктивна питања су какав? и шта ради?) и низу експеримената за груписање речи. Као резултат психолингвистичког истраживања је очекивана семантизација ауторских маркема, објашњење закономерности њиховог деловања, визуализација асоцијативног поља ауторског вокабулара.

Кључне речи: психолингвистика, маркемологија, уметнички текст, рачунарска лингвистика, експеримент

Један од циљева савремених књижевних студија и филологије у глобалу је савладање текстоцентричног приступа и, као резултат, 
концентрација на "живом» аутору, односно аутору као субјекту дискурсивне праксе. Решење тог проблема захтева ширење граница књижевног погледа на уметничко стваралаштво. Кључне речи ауторског текста, или маркеме [1], [2], могу да служе као индикатор додира уметничког текста и «свакодневног» говора његовог аутора. У питању је поређење деловања ауторских маркема у текстовима и у свакодневном коришћењу речи, шта је могуће кад у истраживању узме учешће биографски аутор [3].

Жеља за објективацију и чак формализацију анализе садржаја текстова (најпре књижевних) код филолога се такође појавило доста давно. Првобитно (а нарочито интезивно у 1960-м годинама) се претпостављало да велику перспективу имају у том смислу фреквентативни речници. Што их је више било објављено и анализирано, више се сумњало у њиховој адекватности. Као резултат, у последњих десетак година А.А. Кретов, бавећи се рачунарском лингвистиком, промовисао је идеју, према којој фреквенција речи у тексту није једноставна величина, него резултат интеракције две законитости - језика и текста. Свака форма речи у тексту има два параметра - фреквенцију и дужину. Када фреквенцију речи разматрамо као комплексни изложитељ (субјективно-објективни, текстовно-језични), а дужину речи као једноставан (објективни, језични), онда субјективни фактор (који се садржаја тиче и долази из самог текста) може бити пронађен преко одузимања бројке објективног фактора (тзв. тежине форме речи према дужини) од бројке субјективно-објективног фактора (тзв. тежине форме речи према фреквенције). Пронађена величина је Индекс Текстуалне Маркираности (ИнТеМ), који показује степен субјективне (текстове) тежине ове форме речи у одређеном тексту.

А.А. Кретов и А.А. Фаустов су предложили да се 50 речи (апелативне именице) са максималним ИнТеМом сматрају за маркеме кључне речи, које характеришу специфику текста одређеног аутора. Проналазак маркема је постало полазна тачка нашег интердисциплинарног истраживања.

Као методолошку базу овог интердисциплинарног приступа користимо серију психолингвистичких експеримената, усмерених на откривање семантике и структурних веза кључних речи ауторског лексикона. Добијени експериментални подаци могу добити различиту истраживачку интерпретацију. Прво, пронађена током експеримента 
значења целисходно је да буду упоређена са контекстним значењима речи, које садржи уметнички текст истог аутора. Дакле, подаци психолингвистичких експеримената се показују као важни у књижевној анализи текста. Друго, ово истраживање има непосредну вредност за психолингвистику: ту покушавамо да направимо опис и у перспективи да моделујемо индивидуални лексикон.

Истраживање уметничког текста преко описивања парадигматике и синтагматике кључних речи ауторског лексикона има своју историју у модерним књижевним студијама: ради се о опсежним истраживањима кључних речи, одноосно апелатива, код пизабраних руских писаца и у различитим књижевним добама 18. - почетка 21. века [4], као и о истраживању ауторских концепта и индивидуалног стила с обзиром на кључне речи. Међутим, методике маркемног анализа текста и психолошких истраживања нису биле комбиниране раније.

У експерименталне списке је укључено 50 маркема, издвојених из уметничких текстова одређеног аутора, и 50 «позадинских» лексема. Учесник експеримента није обавештен о принципу одабира речи, нити о циљу истраживања.

Истраживање може бити базирано на 4 врсте експеримената.

1. Слободни асоцијативни експеримент са инструкцијом: Прочитајте реч и поред ње потпишите не мање од три речи које су Вам прве дошле у главу. Што више речи напишете, то боље. Сваки Ваш одговор је тачан. Ако Вам није дошла у главу ниједна реч, ставите иртицу. Ако Вам дошла у главу само једна или две речи, напишиmе их и даље ставите иртицу. Експериментални списак садржи 100 речи. 2. Усмерени асоцијативни експеримент: Напишите фразу, која би садржала одговор на питања "какав?» и "шта ради?». Ако се двоумите са одговором, ставите иртицу. Експериментални списак садржи 100 речи. 3. Експеримент за слободне дефиниције, кад реципијент мора дати дефиницију предложеним речима. У овом експерименту због његовог обима и тежине «позадинске» речи нису укључене у списак. 4. Серија експеримената за груписање (експериментални списак садржи 100 речи.). Учесник експеримента прво мора да састави од предлажених речи тематичке группе и да назив свакој од њих. После све првобитне речи морају бити подељене у парове према близини семантике (и то је експеримент за симиларе), а речи које су остале без парова, треба одвојити у посебну группу. Затим учинити исто с лексемама супротним по значењу (експеримент за опозите). 
Наведени психолингвистички експерименти служе за разнолику анализу речи које се разматрају. Определи се, прво, степен њихове актуелности за реципијента; друго, њихова семантика; треће, њихове везе у индивидуалном) лексикону учесника експеримента. Дакле, рад на интерпретацији података експеримента може бити реализован у више праваца, и то су: семантизација одговора реципијента, квантитативна анализа резултата експеримента и моделовање асоцијативно-вербалне мреже.

Механизам семантизације кључних лексема према подацима психолингвистичких експеримената је детаљно описан у раду [5].

Размотримо детаљније алгоритам изградње асоцијативних поља кључних речи. При стварању таквог поља користе се подаци свих проведених експеримената. Уколико поље може да се формира само од именица, у центру пажње испитивача су само они одговори који их садрже.

На почетку истраживања асоцијативно поље се претставља као таблица у којој су смештене речи подстицаја (стимулисања) и речи реакције. Између оних других могу бити такве речи које опет служе као подстицај за појаву других реакција. Нарочито је забележљиво да при преласку од речи стимулисања до њеног симилара (опозита), а затим од исте реакције која већ постала потстицај до њеног симилара (опозита) ми се враћамо првобитној стимулисајућој речи, тако да процес стварања асоцијативног низа (ланца) почиње поново. 3бог тога се бесконачна варијанта стварања асоцијативног поља искључује.

Оне лексеме које предвиђају наставак низа предлажемо да се назову «речи прекидачи» (или «прекидачи»). Ако се у неком моменту у неком ступцу појављује неколико подједнаких речи, даље се поље формира од било које из њих, али се притом записује укупни број таквих речи. Ако стимулишућа реч даје више реакција «прекидача», оне се записају у различним редовима истог ступца, и грађење поља се наставља од сваког од њих. Формирање појединечних ланаца се завршава кад се поново појави лексема која се већ сретала раније у претходним ступцима. Такве лексеме не могу имати наставак, зато их зовемо «лексеме закључивачи» (или «закључивачи»). Дакле, формирање асоцијативног поља може бити завршено у једном од следећих случаја:

1. Ако неки корак тог грађења асоцијативног поља доведе до првобитне лексеме. У овом случају треба сваки асоцијативни ланац проследити до момента кад се првобитна лексема појавила као «закључивач». 


\section{Филологија културе}

2. Ако све речи-реакције у неком моменту постану само «закључивачи» и/или лексеме без могућности наставка.

Размотримо пример развијања асоцијативног поља маркеме печаль 'туга' (маркема је издвојена из поетске збирке Г.М. Умивакине «Родительская суббота»). У свакој ћелији таблице бр. 1 је наведен пун одговор рецепијента; у заградима су речи, које нису учествовали у повећању низа асоцијација.

Таблица 1.

\begin{tabular}{|l|l|l|l|}
\hline $\begin{array}{l}\text { печаль } \\
\text { 'туга' }\end{array}$ & $\begin{array}{l}\text { СА (стихи 'песме'), песня } \\
\text { 'песма', (разлука 'растанак') }\end{array}$ & $\begin{array}{l}\text { СА печаль 'туга', друзья 'пријатељи', } \\
\text { колыбельная 'успаванка' }\end{array}$ & 1 \\
\hline & $\begin{array}{l}\text { ДА (печальная 'тужна', греет) душу } \\
\text { 'загрева душу' } \\
\text { невозвратном) 'успомена } \\
\text { (на неповратно)' }\end{array}$ & СИМ улыбка 'осмех' & 2 \\
\hline & СИМ душа 'душа' & $\begin{array}{l}\text { СА любовь 'љубав', стихи ‘песме', } \\
\text { полёт 'лет' }\end{array}$ & 4 \\
\hline 1 & ОП улыбка 'осмех' & СИМ воспоминание 'успомена' & 5 \\
\hline & 2 & 3 & \\
\hline
\end{tabular}

Условне ознаке:

СА - слободни асоцијативни експеримент

ДЕФ - експеримент за слободне дефиниције

СИМ - групи, симиларни

ОП - групи, оппозиције

Изграђено асоцијативно поље може опет бити анализирано у оквиру квантитативног истраживања. Међу важним параметрима су следећи:

1) квантитет речи коришћених као «прекидачи» (и квантитет случаја коришћења таквих речи);

2) квантитет речи коришћених као «закључивачи» (и квантитет случаја коришћења таквих речи);

3) део маркема «прекидача» у речима «прекидачима» (и фреквенција коришћења маркема);

4) део маркема «закључивача» у речима «закључивачима» (и фреквенција коришћења маркема); 
5) број стубаца и редова у таблици одговарајућег асоцијативног поља (број корака и ступања, односно операција).

Осим тога, детаљнија анализа асоцијативних поља тражи да се зна колико пута се свака лексема из експерименталног списка користила као прекидач или као закључивач (и то у једном асоцијативном пољу или у свим пољима укупно).

Статистика за сваку реч из експерименталног списка може бити добијена уз помоћ разноврсних компјутерских програма, које раде на основи споменутог алгоритма грађења асоцијативног поља. Примери података добијених на тај начин су наведении у таблици бр. 2: истражени материјал се користио као експериментални списак током експеримента у ком је учествовала вороњешка песникиња Галина М. Умивакина и узет је из њене збирке песама «Родительская суббота»).

\section{Таблица 2.}

\begin{tabular}{|l|l|l|l|l|l|}
\hline Лексема & $\begin{array}{l}\text { Број лексема } \\
\text { «рекидача» }\end{array}$ & $\begin{array}{l}\text { Број лексема } \\
\text { «закључивача» }\end{array}$ & $\begin{array}{l}\text { Део маркема у } \\
\text { «пекидачима» }\end{array}$ & $\begin{array}{l}\text { Део маркема у } \\
\text { «закључивача» }\end{array}$ & $\begin{array}{l}\text { К а к } \\
\text { (ступањ) }\end{array}$ \\
\hline воспоминание & $4(5)$ & $1(1)$ & $0,75(0,80)$ & $1,00(1,00)$ & 410 \\
\hline бесконечность & $53(56)$ & $36(59)$ & $0,68(0,70)$ & $0,58(0,68)$ & 1497 \\
\hline разговор & $35(37)$ & $24(31)$ & $0,66(0,68)$ & $0,63(0,65)$ & 1159 \\
\hline вдохновение & $1(1)$ & $0(0)$ & $0,00(0,00)$ & $0,00(0,00)$ & 32 \\
\hline детство & $16(19)$ & $10(14)$ & $0,63(0,63)$ & $0,70(0,79)$ & 830 \\
\hline простор & $4(4)$ & $1(1)$ & $0,75(0,75)$ & $1,00(1,00)$ & 313 \\
\hline интеллигенция & $41(45)$ & $27(39)$ & $0,71(0,73)$ & $0,56(0,64)$ & 1469 \\
\hline прощание & $18(19)$ & $8(9)$ & $0,72(0,74)$ & $0,63(0,67)$ & 539 \\
\hline счастье & $30(31)$ & $21(25)$ & $0,67(0,68)$ & $0,57(0,60)$ & 1053 \\
\hline легкомыслие & $29(30)$ & $18(22)$ & $0,62(0,63)$ & $0,67(0,73)$ & 1844 \\
\hline праздник & $50(58)$ & $36(57)$ & $0,68(0,69)$ & $0,56(0,65)$ & 1098 \\
\hline фотография & $37(42)$ & $24(35)$ & $0,65(0,64)$ & $0,58(0,66)$ & 1666 \\
\hline поединок & $0(0)$ & $0(0)$ & $0,00(0,00)$ & $0,00(0,00)$ & 21 \\
\hline календарь & $55(61)$ & $36(55)$ & $0,65(0,67)$ & $0,53(0,64)$ & 1197 \\
\hline позвоночник & $28(29)$ & $18(22)$ & $0,64(0,66)$ & $0,67(0,73)$ & \\
\hline
\end{tabular}

Детаљније о статистичком аспекту истраживања: [3], [6]

Као што видимо, у случају Г.М. Умивакине број активних маркема се мења од око 6 од десет, а маркеме у асоцијативним пољима се појављају скоро с истом фреквенцијом. Тако да, ако је доказивано да постоје објективни семантички критеријуми, 
који објашњавају зашто баш те маркеме писац активно користи у спонтаној речи (тј. идентификује као своје), онда то отвара пут за састанак са аутором, да се види какав је био писац изван својих књижевних текстова, односно, какавим се описао у њима. И у овом случају психолингвистика, основана на компјутерној лингвистици, постаје инструменат књижевне херменеутике.

\section{Литература}

Кретов, А. А. Метод формального выделения тематически нейтральной лексики (на примере старославянских текстов) / А.А. Кретов // Вестн. Воронеж. гос. унта. Серия Системный анализ и информационные технологии. 2007. № 1. С. $81-90$

Кретов, А. А. Понятие маркемы: методика выявления и практика использования / А.А. Кретов // Универсалии русской литературы 2. Сборник статей / Под ред. А.А. Фаустова. - Воронеж: НАУКА-ЮНИПРЕСС, 2010, С.138-153.

Фаустов, А.А. О субъектно-рефлексивном анализе литературного текста. Эпизод II. Маркемы в индивидуальном лексиконе Г.М. Умывакиной: общий обзор / А.А. Фаустов, М.Я. Розенфельд // Вестник Воронежского государственного университета. Серия: Лингвистика и межкультурная коммуникация. - 2013. - № 2. - С. 95-100.

Универсалии русской литературы: сборник статей. - Воронеж: Воронежский государственный университет, 2011. - 441 с.

Фаустов, А.А. О субъектно-рефлексивном анализе литературного текста. Эпизод І. / А. Фаустов, М.Я. Розенфельд // Филологические записки: Вестник литературоведения и языкознания. - Вып. 31. - Воронеж: Издательскополиграфический центр «Научная книга»; Воронежский государственный университет, 2012 - 2013. - С. 287-309.

Фаустов, А.А. Алгоритм построения ассоциативного поля слов (по результатам психолингвистических экспериментов с ключевыми словами автора) / А.А. Фаустов, М.Я. Розенфельд, Н.Ю. Свиридова, И.Е. Воронина // ... 2016. 